\title{
HETEROGENEOUS \\ ENTREPRENEURSHIP \\ AND THE SUNDAY TIMES \\ RICH LIST
}

ANTHONY J. EVANS*

TOBY BAXENDALE**

\section{I \\ INTRODUCTION: \\ HETEROGENEOUS ENTREPRENEURSHIP}

It may appear surprising that economists devote such little attention to the heterogeneity nature of entrepreneurship, however there are several possible explanations. The concept represents a well-known tension between typical economic theory and the concept of entrepreneurship itself. When Baumol (1968) and Kirzner (1973) wrote their seminal works they were attempting to respond to a perceived neglect of the entrepreneur within neoclassical economics. The explosion of entrepreneurship research since then has not been comfortably reconciled with formal models, and indeed empirical studies have a tendency to lapse into psychological profiling. It might be argued that such profiling (be it in terms of gender, race, age, experience, education, IQ, marital status, employment history, etc) does make entrepreneurs heterogeneous, however this differs from the way in which we use the term. «Heterogeneity» does not merely mean «differentiated» but ties into a deeper methodological debate about the nature of scientific analysis. In short, heterogeneity is an aspect of the broader concept of subjectivism. At a basic level subjectivism implies

* anthonyjevans@gmail.com. Assistant Professor of Economics, ESCP Europe.

** tbaxendale@seafoodholdings.co.uk. Founder and CEO, Seafood Holdings. 
that individuals can interpret events in different ways, and as a consequence of this we expect a diversity of action that is glossed over when people are modelled as homogenous agents.

Having said this, it's important to recognise the diversity of approaches and methodologies within the economics profession. For example, although the neoclassical system is liable to eschew premises that aren't tractable, Austrian-school economists do tend to emphasise subjectivism and heterogeneity. But whilst this is strikingly evident in capital theory (see Lachmann 1956) it is curious to note that a similar attitude towards entrepreneurs themselves is underplayed. In short, since Austrians emphasise the functional qualities of entrepreneurship they treat entrepreneurs as homogenous blobs. This paper intends to strike a middle ground between homogeneity and psychological particularism by deconstructing the entrepreneur (Evans and Baxendale 2008).

Such a middle ground ultimately rests on knowledge assumptions. ${ }^{1}$ Foss (1994) suggests an approach to the theory of the firm that takes entrepreneurship seriously, focusing on knowledge. He argues that when economic agents acquire new knowledge they can sell their service through a contract, utilise it for arbitrage, or start a new firm. However such contracts would always be incomplete - mainstream economists might point to asymmetric information, whilst subjectivists would also stress the inherent intersubjectivity of knowledge. Thus Foss shows that in many cases firms are the institutional mechanism through which knowledge is acted upon - potential entrepreneurs compare their market wage to the expected returns from launching a new venture, and then use contracts for the more straightforward task of hiring labour. This essentially leads to a clearing process as agents choose to either initiate their own plans or to form part of the plans of others.

Chu (2001) provides a general equilibrium model in which «entrepreneurial skill» is incorporated, defined as «the intrinsic ability in capturing market opportunity and organizing a human network to deliver a product» (p.4). Rather than using education

${ }^{1}$ Note the distinction between knowledge assumptions and cognitive capacity. It is the latter that leads to the sort of psychological particularism that typifies most entrepreneurship studies and to which we seek to avoid. 
as a measure of this form of human capital, the author creates what is in essence a sorting model, whereby agents become entrepreneurs if their managerial skill set exceeds a certain level. Whilst this introduces a certain degree of heterogeneity, it amounts to little more than claiming that different people posses different skills. Landerretche (2006) introduces heterogeneity by modeling entrepreneurs with different endowments of wealth and «quality of entrepreneurial ideas» (p. 4).

Shleifer and Summers (1990) provide a simple means to extend the concept of entrepreneurship by distinguishing between two «types» - arbitragers and «noise» traders. Although they focus on financial markets as opposed to entrepreneurs more generally, it is this utilisation of types, as opposed to empirical detail, that helps to retain methodological subjectivism.

Howden (2010) uses the concept of information cascades, arguing that second-order users of knowledge have less direct knowledge of credit conditions. We can augment this by recognising that one form of knowledge that is relevant to entrepreneurs is knowledge of economic theory with regard to monetary policy. In other words, we do not expect money illusion and the signal extraction problem to affect all entrepreneurs uniformly. It is possible that some entrepreneurs do recognise a credit boom, and although they play with the easy money they do so cautiously, and with an expectation that it will run out and they will need an exit plan. Of course this doesn't mean they will not be burnt, but it does imply a distinction between those who are in the market despite easy money, and those who are there because of it.

The basic theory is that expansion of the money supply by the central bank creates "cheap money» that otherwise wouldn't be available for lending. We can demonstrate when these periods occur, but our interest is in comparing those cycles to the changing fortunes of individual entrepreneurs. We believe that there's a type of entrepreneur who's relatively insensitive to interest rate changes, and therefore makes consistent profits, whilst another type of entrepreneur can only enter the market when cheap money's available, and they' $\mathrm{d}$ therefore be most likely to go bust when conditions change. Credit expansion (or «loose monetary policy») entices marginal entrepreneurs into the market, and the 
very same ones will be the first to leave when monetary policy tightens. ${ }^{2}$ Rather than the rational expectations story where interest rates affect borrowers uniformly, the boom and bust is caused by the actions of a small number of marginal entrepreneurs, who're only in the market because of mixed signals (i.e. not because they're «irrational»).

We have a large, relatively stable population of entrepreneurs who take advantage of cheap credit but have the capacity to keep an eye on the chairs when the music stops. But there is also a small, volatile subset of entrepreneurs who are enticed into a market that cannot sustain them (Evans and Baxendale, 2008, p. 91).

By taking a more heterogeneous approach to entrepreneurship we are able to draw attention to the driver of economic activity. In this case the marginal entrepreneur is the one who is only able to acquire resources when interest rates are artificially low.

Despite a widespread fascination for wealth, the systematic study of the wealthy is a relatively new phenomenon. Forbes magazine produce an annual list of the world's richest people, with publicly available data going back to $2000 .{ }^{3}$ Whilst this remains perhaps the more famous, alternative rich lists have emerged across the world with most major countries having at least one definitive version. There are also regional lists, such as Central and Eastern Europe's «Najbogatsi Europejczycy Europy rodkowej i Wschodniej,» ${ }^{4}$ and the «World's 50 richest Arab businessmen \&

2 Although we present the argument in terms of heterogeneity of entrepreneurs, it might be better to view it as heterogeneity of entrepreneurial plans. In other words it is the entrepreneurial calculation that is the focus and not the entrepreneur per se.

3 See «Forbes rich list: ten years of top tens» The Guardian, March $11^{\text {th }} 2010$ [http:/ / www.guardian.co.uk/news/datablog/2010/mar/11/forbes-rich-list-topten-carlos-slim].

${ }^{4}$ http://najbogatsieuropejczycy.wprost.pl/ 
women» compiled by Arabian Business.com. ${ }^{5}$ The appendix provides a thorough list of national rich lists.

Since our focus is on the UK economy we have decided to use the Sunday Times Rich List. It first appeared in $1989^{6}$ and as of 2010 compiles estimates of the wealth of the 2,000 richest people in the UK. ${ }^{7}$ It is important to recognise the drawbacks of using rich lists more generally, and this one in particular. The fact that these are estimates cannot be emphasised enough, and we acknowledge that they will differ significantly from actual wealth. We do not make an assumption that error terms are likely to cancel out, and therefore need to be vigilant to the potential that there are systematic tendencies to over or underestimate wealth. Despite utilising a large degree of estimation (when sufficient evidence exists), The Sunday Times list will leave out individuals that almost certainly should be included. In this regard it is an inherently conservative measure, and should be viewed as a lower bound,

This list is based on our estimates of the minimum wealth of Britain's 1,000 richest people or families. The actual size of their fortunes may be much larger than our figure.

The Sunday Times Rich List 2010: Rules of engagement» The Sunday Times, April $23^{\text {rd }} 2010$.

The compilers do not have access to personal bank accounts, and therefore exclude these from the measure. However one of the chief criticisms of the rich list is not applicable to our use - that there is a high degree of ambiguity as to who is elegible to appear on the list. As the «Rules of Engagement» state,

The 1,000 include people who may not be British citizens, such as Hans Rausing from Sweden, but who live and work in Britain. In this age of globalisation, where London is regarded as the centre

\footnotetext{
5 http:/ / www.arabianbusiness.com/richlist?r=1\&r=1

${ }^{6}$ Although in 1988 the forebear was produced for «Money» magazine, see «fResource talks to Philip Beresford» [http://www.thinkresource.org/node/1427].

7 At a regional level the Midlands Business Insider, North West Business Insider, South West Business Insider, Yorkshire Business Insider and Birmingham Post all provide well-respected rich lists.
} 
of a new financial elite, we also include people who are married to Britons, who have strong links with Britain, estates and other assets here, or who have backed British political parties, institutions and charities, and often seem more British than the British.

The Sunday Times Rich List 2010: Rules of engagement» The Sunday Times, April 23 2010.

For our purposes the fact that it isn't constrained to British citizens is not important, as our chief concern is the strength of commercial interests within the UK. Indeed this encompassing approach helps to mitigate a possible problem of capturing too much inherited wealth. We are not claiming that such rich lists perfectly capture the concept of «entrepreneurship», and would not define everyone on the list as an «entrepreneur». In this regard the lists are really picking up «funds» rather than measures of an entrepreneur's fortunes. This might suggest that a better measure would be venture capital (VC) data or other sources that focus on start-ups or business owners. We avoid this on the grounds that we wish to retain a functional approach to entrepreneurship, whilst retaining a methodologically individualistic attention to agency. It is true that by only looking at the "richest» we have a selection bias that precludes the genuinely «marginal» entrepreneurs. However we feel this top down approach is an appropriate place to start.

We are not the first to make use of such data sources. Hazledine (1997) appears to be a pioneer of this approach, utilising the National Business Review's New Zealand Rich List as a data base to conduct quantitative analysis on whether fortune accumulation is more likely to stem from «competitive» industries. Beaverstock, Hubbard and Short (2004) perform a more qualitative study of the "super-rich», arguing that whilst much empirical work is undertaken on people living below the poverty line, considerably less attention is given to the very wealthy. They acknowledge the difficulties of using such lists, but argue,

While the way these estimates of net worth are compiled leaves some margin for error, in many ways they are a useful barometer of the levels of wealth accruing to the super-rich (Beaverstock, Hubbard and Short 2004, p. 404). 
Ultimately we feel that despite these drawbacks The Sunday Times Rich List remains the definitive version and provides a valuable source of information for researchers. Given that we anticipate researchers making increasing use of this data, we feel the admittedly sparse and qualified nature of its current form shouldn't preclude its use in a pilot study. Since it uncovers the rise (and fall) of individual wealth it can be compared to underlying economic conditions. This helps us to understand the types of entrepreneur that prosper during a recession, and those who get weeded out.

III

\section{METHODS}

The data was compiled using a mixture of online information and hard copies. The Sunday Times has resisted making an electronic version of the Rich List available, out of an understandable fear that rivals would mimic the methodology and data. However the do have online, searchable records for the richest 1,000 for 2002$2007,{ }^{8}$ and at the time of writing the richest 2,000 for 2010 are available behind a pay wall. ${ }^{9}$ We utilised hard copies of the 20062010 Rich Lists to verify data and cover the missing period. Since the database itself is not publicly available we created a shadow database manually.

We began be entering the top 100 richest people in 2006, and then used our data sources to complete this for 2007, 2008, 2009 and 2010. We then went through the top 100 for 2010, added any new people, as well as tracing everyone's wealth back through 2006. Finally we completed the top 100 for 2002, and followed their wealth until 2005. This leaves us with a database of 168

8 http://www.timesonline.co.uk/richlist/start/0,,2002-1,00.html http:/ / www.timesonline.co.uk/richlist/start/0,,2003-1,00.html http:/ / www.timesonline.co.uk/richlist/start/0,,2004-1,00.html http:/ / www.timesonline.co.uk/richlist/start/0,,2005-1,00.html http:/ / www.timesonline.co.uk/richlist/start/0,,2006-1,00.html http://www.timesonline.co.uk/richlist/start/0,,2007-1,00.html

9 http:// features.thesundaytimes.co.uk/richlist/live/ 
people - everyone who has been one the top 100 richest people in the UK in 2002, 2006 or 2010 (these three years act as our markers).

Of course we could go into more detail, and we anticipate future studies of this sort to extend the range of data in several directions. The intermittent years could be investigated, to take into account those who entered into the top 100 and then left again between our markers. ${ }^{10}$ The data can be extended chronologically, to take into account the years preceding 2002 (which do not currently have electronic records) and indeed should be updated for subsequent years going forward. Also, and perhaps most importantly, the scope can be extended to include all those in the top 1,000 , which would increase the dataset by an approximate factor of 10 .

As a pilot study we feel that the boundaries we have set are appropriate. As previously discussed, the quality of the rich list has been increasing over time, so we would be concerned about extending it back any further (especially since errors are not corrected retrospectively). Given that our focus is on the 2008/09 financial crisis and that this is intended to be an illustrative study we feel that the gain in coverage would be offset by a decline in the average quality of data. We also believe that the quality of the wealth estimates is higher for people higher up on the rich list. This point requires some clarification.

It is true that if there is a margin or error in each estimate, these will be amplified for people with higher wealth. Indeed such people are likely to hide more of their wealth and thus we might expect (and indeed observe) large quantity adjustments from year to year. However it seems clear that more effort is applied to dealing with these cases than with the wealth of people lower down the list. This can be seen by the fact that for people with

10 For example Odfjell was a new entry in 2010 and since they do not appear in the top 100 in 2002 or 2006 we estimate their wealth for 2002-2009. However they do appear in the 2008 rich list, and therefore we could use their actual value if we were looking at intermittent years. We note that our estimate $(£ 755 \mathrm{~m})$ is significantly different from the actual value $(£ 150 \mathrm{~m})$ but in this case since the person counts as an immigrant they are excluded from the data set anyway. 
relatively low levels of wealth their «estimate» is rounded and shared by a number of other people (for example in 2002 there are about 38 people with wealth of $£ 35 \mathrm{~m}$ ). Indeed this demonstrates an important fact about rich lists - they are examples of investigative journalism rather than established data sources. We have previously justified why we believe this should not preclude their use, but we face an important choice. One option is to ignore this fact, build as large a database as possible, and use the law of large numbers to compensate for errors of compilation. An alternative option - and the one we take - is a more cautious approach that strips away contestable data points to leave us with a smaller sample. Since this is a pilot study we proceed conservatively and therefore require a dataset that is manageable on a case-by-case basis. If we increased the data set by a factor of 10 we would not be able to conduct additional research on every single member of the database.

Such individual analysis is required to ensure we are picking up changes in actual wealth, as opposed to changes in residency, computational errors, or other such factors. Therefore our database serves as a basis from which several important adjustments are made. Firstly, it is obvious that one of the main explanations for new entries into the rich list is foreign nationals that move into the UK. Whether they formally immigrate or not their entry does not reflect an increase in their wealth, but changes in their residency status that alerts the compiler of the rich list to start including them. Consequently we take the conservative decision to exclude those who fit our definition of «immigrants». ${ }^{11}$ Similarly there are those who drop out of the rich list, not due to a decline in wealth, but because of their residency status. We define these as «emigrants» and similarly exclude them. ${ }^{12}$ Deaths present a similar challenge, since we do not wish to imply that these people leave the list for financial reasons. Consequently in the case of people who have passed away, we exclude them from the list

11 These are Abramovich, Al-Tajir, Berezovsky, Bertarelli, Blavatnik, Bronfman, David/Leventis, Gandur, Gutseriyev, Hamied, Hines, Kim, Odfjell, Oppenheimer, Said, Seabra, Shvidler, Usmanoz, and Zabludowicz.

12 These are Bredenkamp, Picasso, Hinduja. 
for all periods. ${ }^{13}$ The final rationale for excluding people is what we label «missing in action». These are people who leave the list but we find no evidence for them either emigrating or passing away. We believe it would be misleading to make estimates of their wealth, therefore exclude them altogether. ${ }^{14}$

Having compiled the database in the manner described, there remained a number of incomplete data points. We made estimates based on the following criteria. For those who fall outside the top 1,000 but then make a subsequent appearance as a new entry we estimate their intermediate wealth based the midpoint of known data points. ${ }^{15}$ We feel this may underplay the amount of volatility however deem it more appropriate than assuming their wealth falls to zero. In the case of bankruptcies we mark their subsequent wealth as 1 (this avoids calculation problems if we were to use a zero value). ${ }^{16}$ For those who come into the top 100 but fall out again, we estimate their wealth based on the threshold required to enter the top $100 .{ }^{17}$ For those who fall out of the top 1,000 altogether we make the conservative assumption that their future wealth is equal to the threshold to enter the top $1,000 .{ }^{18}$ Finally, there are those who enter the top 100 as a new entry to the rich list. In these cases we estimate their prior wealth as being equal to the threshold to join the top $100 .{ }^{19}$ Once these amendments are made we are left with a data set of 135 people.

13 These are Manton (2006), Van Vlissengen (2006), Landon (2008), Templeton (2008), and Sorensen (2010). Although Raymond also died his wealth was bequeathed to James who remained on the list, and we therefore condense them into one entry.

14 These are Khan, Florier-Destezet, Khalili and Mantegazza.

15 This is utilised for Blavatnik (2007 \& 2009) Bromilow (2009), Panayioutou (2009) and Shifrin (2009). In the case of Ratcliffe (2009) we note his exclusion is due to a write down of assets and thus use the threshold for the top 1,000, «As negotiations with banks extended over the period of the 2009 Rich List, we took the 57 -year-old out of our calculations, but he convinced most of the 230 banks owed money to change the loan terms» The Sunday Times, [http:/ / features.thesundaytimes.co.uk/ richlist/live/richlist/view/main/1/rank/-/ratcliffe\#list].

16 These are Bjorgolfsson, Halabi and Hunter.

17 These are Cha, Christodoulou.

18 These are Gubay, Johnson, Quinn.

19 These are Agarwal, Asfari, Calder, Coombs, De Leon/Parasol, Dikshit, Elman, Frederiksen, Goyal, Grant/Gordon, Green (Peter), Howard, Knaster, Lemos, Miller, Moritz, Parker. 
Since our database rests on the validity of the underlying rich lists, it is appropriate to highlight several things that subsequent research might need to correct - aspects involved in the compilation that hamper efforts to use this for our purposes. Firstly is the atypical acquisition or liquidation of assets. In a large enough sample one might suspect these effects to be downplayed, but it is obvious that larger changes in an individuals wealth represent unique events as opposed to endogenous factors. ${ }^{20}$ Secondly is the treatment of joint wealth. Since many individuals put part of their wealth in the name of other people (e.g. wives or family members) events such as divorce can have a large impact, as can the compiler's judgment regarding when to treat family members as part of the same unit. ${ }^{21}$ Where possible we reduce the impact of such changes in the individuals, conscious of the fact that we are really focusing on funds (with individuals as proxies) and less concerned on actually understanding the net wealth of a given person. Thirdly, there are noticeable changes in wealth that do not have obvious explanations, indicating that they represent a change in data compilation (such as counting a hitherto unknown source of wealth or alteration of methodology) rather than any organic change. In such cases we make efforts to validate the findings ourselves, but ultimately remain in the hands of the rich list compilers. ${ }^{22}$

${ }^{20}$ Coombs and Livingston seem to provide examples of big asset deals that skew their results.

${ }^{21}$ For example, Bernie and Sylvie Ecclestone divorced in 2009 and therefore one data point splits into two separate ones. In addition, prior to 2009 Lord Rothschild and Nat Rothschild account for a joint entry, and after this receive their own (and consequently their wealth is seen to plummet). We compensate for this by treating them as one entity throughout the study. We also note that David Thompson's wealth is combined with Richard Thompson's in 2004/5 accounting for the observed spike.

22 Consider the halving of Sainsbury's wealth from 2002 to 2003, or the rise of Reuben's wealth in the same period. We also note the fact that Gaston Murray disappears from the list, but we utilise the Birmingham Post's rich list as an estimate for the missing periods, see http:/ / www.birminghampost.net/birmingham-business / richlist/richlist2010/2010/02/03/1-12-jacques-gaston-murray-480m-625m-6523325755724/ 


\section{FINDINGS}

There is little doubt that Rich Lists demonstrate the broad contours of a credit boom and bust. In the 2009 Forbes Rich List there were 793 billionaires, 656 of whom lost money during the course of the preceding year, with just 44 becoming richer. ${ }^{23}$ The average net worth of billionaires that are under 40 fell $30 \%$ from 2008 to $2009 .{ }^{24}$

The wealth of Irelands richest 250 people fell by $25 \%$ in 2009 , the sharpest fall in its history. ${ }^{25}$ In Ukraine, the combined wealth of the top 50 fell to $\$ 28.9 \mathrm{bn}$, which is $\$ 2 \mathrm{bn}$ less than the wealth of the richest person in 2008. ${ }^{26}$

When our dataset is analysed, we find that such is the volume of activity it is impossible to gage general impressions. Indeed this is compounded by the fact that whilst rapid accumulations of wealth are clearly observable (the maximum growth rate has no upper bound), rapid dissolution is masked by the fact that growth rates cannot be negative once someone is bankrupt (i.e. there is a clear lower bound).

Despite this we have several results. Firstly, figure 1 shows the relationship between two wealth thresholds, mean wealth, and our measure of the money supply, MA (see Evans and Baxendale 2010 for details on compilation).

Threshold 100 is the level of wealth required to break into the top 100 richest people, for each given year. Threshold 1,000 is the amount to reach the list itself. The mean is the average net wealth of everyone in our database. Percentage changes are shown to mitigate differences in scale. Changes in MA (shown on the secondary axis) is our measure of credit conditions. ${ }^{27}$ As can be seen,

23 «Roman Abramovich down to his last $£ 3$ billion as credit crunch cuts world's biggest fortunes by a quarter» Daily Mail 12 $2^{\text {th }}$ March 2009.

${ }^{24}$ See «Youngest billionaires lose money» BBC News, April 30 2009.

25 Note also that this was only the third year on record that the combined wealth had fallen. See «Bonfire of the billionaires strikes at Irish fortunes» by Colm Murphy and Colin Coyle, The Sunday Times, April $26^{\text {th }} 2009$.

26 See «50 Richest Ukrainians» by Mark Rachkevych, Kiev Post, June 11 2009.

27 Since the Sunday Times Rich List is compiled in January of each year we take the January year-on-year measure of the money supply. 
FigURE 1

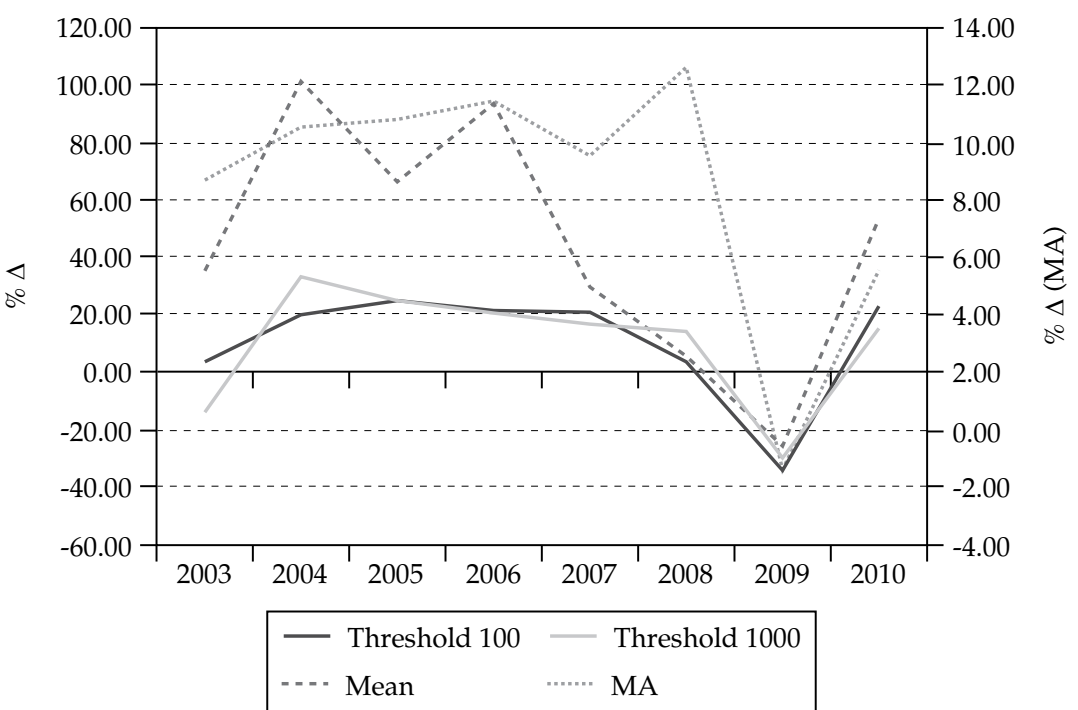

not only is there a clear correlation between the various thresholds and mean wealth, this coincides with the changes in the money supply. The correlations between the percentage changes are given in the table below (Figure 2):

Figure 2

\begin{tabular}{ccc}
\hline Variable $Y$ & Variable X & $r$ \\
\hline THRESH 100 & MA & 0.755958906 \\
\hline THRESH 1,000 & MA & 0.772210172 \\
\hline MEAN & MA & 0.59375762 \\
\hline
\end{tabular}

Figure 2 takes a more focused approach and shows how the change in the money supply coincides with movements in and out of the database.

We show the number of new entries and the number of people who fall out of the list in each year. Although the numbers are small, of the 3 fallouts of 20092 of them were new entries into 
Figure 3

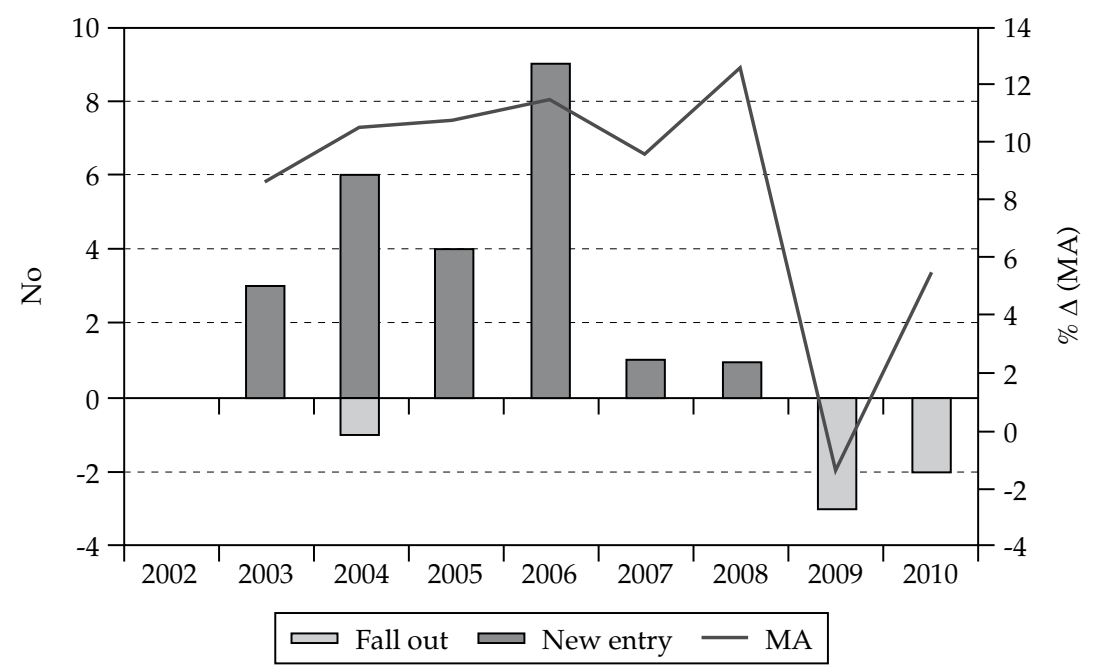

the top 1,000 previous years. ${ }^{28}$ Of the 2 fallouts in 20101 of them was a new entry into the top 100 in previous years. ${ }^{29}$ Therefore of the 5 fallouts in 2009 and 2010 only 2 of them had been in the top 100 since $2002 .{ }^{30}$

We could extend this analysis further, and look at the fallout from the top 100, but these findings are revealing. They demonstrate that those who fell out of the top 100 as a consequence of the credit crunch were disproportionately likely to have been recent new entries.

\section{$\mathrm{V}$ \\ CONCLUSION}

This paper is admittedly modest in its aims. Due the general dearth of research based on rich lists we have constructed from

28 Bjorgolfsson in 2006 and Halabi in 2004.

${ }^{29}$ Quinn in 2003.

${ }^{30}$ Hunter and Gubay. 
scratch a modified database taken from The Sunday Times' published information. We made numerous adjustments in light of issues with the data quality and use them to present preliminary results. Clearly much more work can be done to expand the quality and scope of this kind of data, but as a method to uncover how entrepreneurs have fared in light of the recent boom and bust cycle our results are telling. If such results can be replicated, modified and extended, we can strengthen our understanding of who the marginal entrepreneurs are, and continue to deconstruct the homogeneous nature of entrepreneurship to create a genuinely heterogeneous approach.

\section{BIBLIOGRAPHICAL REFERENCES}

BAUMOL, W. (1968): «Entrepreneurship in Economic Theory», American Economic Review.

Beaverstock, J.V., Hubbard, P., and Short, J.R. (2004): «Getting away with it? Exposing the geographies of the super-rich» Geoforum, 34(4): 401-407.

CHU, T. (2001): «Vertical specialisation with heterogeneous entrepreneurs: can trade promote industrialisation in developing countries?» Minnesota Centre for Economic Research, Paper N. $\stackrel{\circ}{310}$.

Evans, A. J. and Baxendale, T. (2008): «Austrian business cycle theory in light of rational expectations» the role of heterogeneity, the monetary footprint, and adverse selection in monetary expansion» The Quarterly Journal of Austrian Economics, 11(2): 81-94.

EVANS, A. J. and BAXENDALE, T. (2010): «The monetary contraction of 2008/2009: Assessing UK money supply measures in light of the financial crisis» Available at SSRN: http:// ssrn.com/abstract $=1416922$

Foss, N.J. (1994): «The Theory of the Firm: The Austrians as Precursors and Critics of Contemporary Theory» Review of Austrian Economics 7 (1): 31-65.

HAZledine, T. (1997): «How did the wealthiest New Zealanders get so rich?» New Zealand Economic Papers, 31(1): 35-47. 
Howden, D. (2010): «Knowledge shifts and the business cycle: When boom turns to bust» The Review of Austrian Economics, 2010, vol. 23, issue 2, pages 165-182.

KIRZNER, I.M. (1973): Competition and Entrepreneurship, University of Cambridge Press.

LachmanN, L. (1956[1981]): Capital and its Structure. New York University Press.

LANDERRETCHE, O. (2006): «Heterogeneous entrepreneurs, creation and destruction: a simple model and some evidence from an emerging market» Working paper

ShleIfer, A, and Summers, L.H. (1990): «The Noise Trader Approach to Finance» Journal of Economic Perspectives, 4(2): 19-33. 
APPENDIX:

A SELECTION OF 2009 RICH LISTS

\begin{tabular}{|c|c|c|}
\hline Country & Title & Publisher \\
\hline Australia & Australian Rich List/ Rich 200 & Business Review Weekly \\
\hline Austria & $\begin{array}{l}\text { Die Liste der } 100 \text { reichsten } \\
\text { Österreicher }\end{array}$ & Oe24.at ${ }^{31}$ \\
\hline Canada & Canadian Rich List/Rich 100 & Canadian Business Online ${ }^{32}$ \\
\hline Denmark & Danmarks Rigeste $2009^{33}$ & Business.dk \\
\hline Estonia & Eesti rikaste TOP 500 & Aripaev ${ }^{34}$ \\
\hline Finland & Suomen 1000 & Kaytannon Maamies \\
\hline France & Les Plus Grandes Fortunes & Challenges $^{35}$ \\
\hline Germany & 10 Richest People & Manager magazin \\
\hline Greece & Greek Rich List & Greek Rich List Publications ${ }^{36}$ \\
\hline Holland & Miljonairs & Quote $^{37}$ \\
\hline New Zealand & New Zealand Rich List & National Business Review \\
\hline Norway & Kapitals 400 rikeste $^{38}$ & Hegnar \\
\hline Poland & 100 Najbogatszych & W Prost ${ }^{39}$ \\
\hline Russia & $\begin{array}{l}\text { Рейтинг российскх } \\
\text { миллиардеров } 2009\end{array}$ & Finance Magazine ${ }^{40}$ \\
\hline South Africa & Rich List & Sunday Times ${ }^{41}$ \\
\hline
\end{tabular}

${ }^{31}$ http:/ / www.oe24.at/wirtschaft/Das-sind-die-100-reichsten-Oesterreicher0503242.ece

32 http:/ / list.canadianbusiness.com/rankings/rich100/2009/intro/Default. aspx?sp2=1\&d1=a\&sc $1=0$

33 http://www.business.dk/bny/danmarks-rigeste-2009

34 http:/ / www.ap3.ee/?PublicationId=31503ED6-39D4-4163-9D98-74AA1E3959CE $\&$ code $=4443 /$ uud_uudidx_444301

${ }^{35}$ http://www.challenges.fr/classements/fortune.php

36 http://www.greekrichlist.com/

37 http://www.quotenet.nl/lijstjes /

38 http://www.hegnar.no/andre_tjenester/rikeste400/

39 http://100najbogatszych.wprost.pl/

40 http://www.finansmag.ru/94502/

${ }^{41}$ Download here: http://www.scribd.com/doc/22780147/November-1-2009 


\section{APPENDIX:}

A SELECTION OF 2009 RICH LISTS (continuación)

\begin{tabular}{|c|c|c|}
\hline Country & Title & Publisher \\
\hline Spain & Los 100 ricos de España & Elmundo Magazine ${ }^{42}$ \\
\hline Sweden & Rich List & $\underline{\text { Veckans Affärer }}$ \\
\hline Switzerland & Die 300 Reichsten 2009 & Bilanz $^{43}$ \\
\hline Ukraine & 50 Richest Ukrainians & $\begin{array}{l}\text { Korrespondent magazine/Kiev } \\
\text { Post }^{44}\end{array}$ \\
\hline United Kingdom & Sunday Times Rich List & The Sunday Times ${ }^{45}$ \\
\hline United States & Forbes 400 & Forbes ${ }^{46}$ \\
\hline
\end{tabular}

42 http:/ / www.elmundo.es/suplementos/magazine/2008/480/1228301893.html

43 http://www.bilanz.ch/leserservice/300reichste.asp?Session=34E9FA58-518E4F01-ABD6-D9002291CF1A\&CID=110\&CPID $=0$

${ }^{44}$ http://www.kyivpost.com/news/nation/detail/43241/

45 http://www.thesundaytimes.co.uk/sto/public/richlist/

46 http://www.forbes.com/forbes-400/ 